\title{
JURNAL ILMU PENDIDIKAN DAN EKONOMI
}

Halaman Jurnal: https://journal.staidenpasar.ac.id/index.php/wb

Halaman Utama Jurnal : https://journal.staidenpasar.ac.id/index.php

\section{Pemberdayaan Potensi Ekonomi Warga Minoritas Muslim Banjar Angansari Desa Kutuh Kintamani Kabupaten Bangli Bali}

\section{Oleh : Kusjuniati}

\begin{abstract}
ABSTRAK
Pemberdayaan ekonomi masyarakat diartikan sebagai kegiatan ekonomi yang dilakukan secara swadaya oleh masyarakat itu sendiri dengan cara mengelolah sumberdaya apa saja yang dikuasainya, dalam rangka memenuhi kebutuhan dasarnya dan keluarganya. Pemberdayaan masyarakat hanya bisa terjadi apabila masyarakat itu sendiri ikut pula berpartisipasi. Pemberdayaan diarahkan guna meningkatkan ekonomi masyarakat secara produktif sehingga mampu menghasilkan nilai tambah yang tinggi dan pendapatan yang lebih layak. Hasil pemberdayaan ekonomi warga banjar Angansari, yaitu dari hasil usaha tani dan ternak, pengadaan homeindustri sebagai usaha sampingan dan penunjang menambah pendapatan keluarga serta pengadaan koperasi syariah sebagai sarana pendanaan usaha bagi warga banjar Angansari yang membutuhkan modal dalam rangka membuka usaha. Dengan adanya pemberdayaan potensi ekonomi diharapkan warga banjar Angansari memiliki peningkatan dalam pendapatan dan bersiap menyongsong pembukaan sektor pariwisata desa Kutuh Kintamani Bangli.
\end{abstract}

\author{
ABSTRACT \\ Empowering the Economic Potential of the Muslim Minority of Banjar Angansari Kutuh \\ Kintamani Village, Bangli Regency, Bali \\ By : Kusjuniati
}

Community economic empowerment is defined as economic activities that are carried out independently by the community itself by managing whatever resources they control, in order to meet their basic needs and that of their families. Community empowerment can only occur if the community itself also participates. Empowerment is directed at improving the community's economy productively so that it is able to produce high added value and more decent income. The results of the economic empowerment of Banjar Angansari residents, namely from the results of farming and livestock, procurement of home industry as a side business and support to increase family income and the provision of sharia cooperatives as a means of business funding for Banjar Angansari residents who need capital in order to open a business. With the empowerment of economic potential, it is hoped that the residents of Banjar Angansari have an increase in income and are ready to welcome the opening of the tourism sector in Kutuh Kintamani Bangli village. 


\section{PENDAHULUAN}

Penduduk Kabupaten Bangli di tahun 2017 sebesar 264.945 jiwa, dengan jumlah penduduk muslim sebesar 2.185 jiwa ${ }^{1}$ Penduduk muslim tersebar diberbagai desa di Kabupaten Bangli salah satunya di Desa Kutuh. Komunitas muslim Banjar Angansari, Desa Kutuh Kecamatan Kintamani berada di daerah perbukitan tepatnya di lereng Gunung Batur Kintamani, sekitar $30 \mathrm{~km}$ dari kota Bangli. Untuk mengunjungi penduduk muslim di desa ini harus melewati kawasan danau batur. Masyarakat Desa Kutuh sebagian besar beragama Hindu. Sedangkan warga muslim di Desa Kutuh hanya 0,1\%. Kondisi ini menarik kami untuk mengetahui lebih jauh tentang kehidupan dan kegiatan warga muslim tersebut. Untuk menuju Desa Kutuh dari Kota Denpasar memerlukan waktu kurang lebih 2.5 jam, dengan jarak tempuh $83 \mathrm{~km}$. Ada beberapa alternative rute dari Denpasar menuju Desa Kutuh diantaranya melalui Plaga, Ubud, Gianyar, dan Payangan. Selama beberapa kali melakukan perjalanan menuju Desa Kutuh, kami lebih memilih melalui Plaga, karena jarak tempuh dapat menghemat waktu 30 menit. Selain itu melalui Plaga melewati daerah wisata Jembatan terpanjang di Bali dan tertinggi di Asia, yaitu jembatan Tukad Bangkung yang diresmikan pada tahun 2016.

Perjalanan menuju Desa Kutuh sangat menegangkan, karena jalan berkelok-kelok dan sempit, serta naik turun perbukitan. Di beberapa ruang jalan hanya bisa dilewati satu kendaraan, dan harus saling menunggu untuk memberikan kesempatan pengendara lainnya lewat. Kanan kiri dari ruas jalan adalah jurang yang ditanami hasil kebun dan sawah. Dalam perjalanan menuju Desa kutuh, memerlukan keberanian dan keahlian berkendara baik roda dua/sepeda motor ataupun roda empat/mobil karena jalanan yang terjal, menurun sangat curam, dan naik dengan kemiringan $45^{\circ}$.

Perjalanan yang penuh risiko dan medan jalan yang berat menyebabkan Desa Kutuh jarang dikunjungi oleh pihak-pihak yang dapat mengembangkan potensi warga muslim di Angansari. Seperti halnya, listrik masuk di Angansari pada tahun 2016, sebelumnya mereka memakai listrik milik warga lain, dengan menyambungkan melalui kabel. Demikian pula dengan air bersih, untuk mendapatkan air bersih masih mengalami hambatan. Penyaluran air

\footnotetext{
${ }^{1}$ http://bali.bps.go.id/statictictable/2018/02/15/33/penduduk-provinsi-bali-menurut-agama-yang-dianut-hasilsensus-penduduk-2010.html.
} 
melalui PDAM, tetapi pada musim kering, air dari PDAM dijatah, karena sedikitnya debit air. Beberapa warga belum memiliki tempat penampungan air (tandon), sehingga terbatas dengan air bersih. Apabila musim kemarau setiap 2 hari sekali air PDAM dialirkan, banyak warga menampung di ember besar, drum, atau wadah untuk menampung air. Terkadang ada warga yang kehabisan air bersih, mereka mencari di sumber mata air, jarak tempuh dan perjalanan menuju sumber air jauh dan terjal. Keadaan ini dialami oleh warga setiap 5 bulan selama musim kemarau, sebaliknya mereka tidak kekurangan air bersih selama musim hujan.

Penduduk muslim Banjar Angansari, Desa Kutuh merupakan minoritas, mayoritas penduduknya beragam Hindu. Kondisi muslim di desa inilah menggerakkan kami untuk meneliti lebih jauh tentang kehidupan dan kegiatan warga muslim tersebut ditengah-tengah keterbatasan ekonomi sosial mereka. Desa Kutuh didiami oleh penduduk asli yang mayoritas beragama hindu dan minoritas beragama muslim, masyarakat muslim Br. Angansari merupakan komunitas muslim kecil yang terletak di pelosok Desa Kutuh, mayoritas masyarakatnya bekerja di kebun dan berternak.

Secara umum perekonomian Desa Kutuh didominasi olek sektor pertanian sedangkan sektor lain adalah perdagangan dan buruh bangunan. Seperti dalam tabel berikut:

Tabel .1 Struktur Perekonomian Desa Kutuh Menurut Mata Pencaharian

\begin{tabular}{|c|l|c|}
\hline No & \multicolumn{1}{|c|}{ Jenis Pekerjaan } & $\begin{array}{c}\text { Jml. Penduduk Menurut } \\
\text { Mata Pencaharian (org) }\end{array}$ \\
\hline 1 & Petani & 1192 \\
\hline 2 & Buruh Tani & 302 \\
\hline 3 & Buruh Bangunan/Pertukangan & 46 \\
\hline 4 & Pedagang & 26 \\
\hline 5 & TNI/Polri & 10 \\
\hline 6 & Pegawai Jumlah & 1577 \\
\hline
\end{tabular}

Hasil pertanian yang utama di Desa Kutuh adalah cengkeh, kopi, pisang, durian dan lain sebagainya. Permasalahan utama yang sering dihadapi masyarakat sekitar dalam rangka meningkatkan produktivitas pertanian adalah ketersedian air dan perubahan iklim yang 
ekstrim, dimana kedua permasalahan ini sangat mempengaruhi produktivitas pertanian di desa ini, karena desa Kutuh yang daerahnya dataran tinggi maka sebagian besar penduduk mempunyai mata pencarian sebagai tani dan buruh tani.

Warga muslim Br. Angansari mayoritas bekerja sebagai buruh tani. Mereka bekerja pada warga Desa Kutuh yang memiliki lahan perkebunan. Mereka bekerja di pagi hari hingga siang atau sore hari. Beberapa dari mereka memiliki hewan ternak, seperti sapi dan kambing, biasanya setelah pulang dari berkebun mereka memberi makan ternak-ternak mereka. Sedangkan yang tidak memiliki ternak, mereka bekerja pada pemilik ternak dengan membersihkan kotoran dan mencari rumput atau makanan ternak. Warga muslim Br. Angansari hanya memiliki kegiatan bertani dan beternak saja, belum memiliki kegiatan ekonomi yang lainnya. Tetapi mereka juga aktif di desa, para bapak melakukan kerja bakti dan kumpul warga, sedangkan para ibu mengikuti kegiatan PKK dan posyandu. Dilihat dari kondisi di atas, pemberdayaan ekonomi warga muslim Angansari belum tampak. Hal ini belum adanya kreatifitas kerja mandiri yaitu, pengadaan kerajinan atau hasil pangan yang diperjual belikan atau home industry untuk menambah penghasilan. Melihat kondisi ini perlu adanya pengembangan potensi warga muslim Angansari untuk meningkatkan perekonomian. Pengembangan potensi ekonomi yang dimaksudkan adalah melalui pemberdayaan ekonomi masyarakat.

\section{PEMBAHASAN}

Berdasarkan penelitian yang telah kami lakukan terhadap potensi ekonomi warga Br.Angansari desa Kutuh Kintamani maka yang diperlukan masyarakat banjar Angansari adalah pemberdayaan ekonomi masyarakat terhadap hasil-hasil potensi ekonomi seperti pertanian, perkebunan dan peternakan. Dengan adanya pengembangan hasil-hasil pertanian, perkebunan dan peternakan serta potensi ekonomi lainnya diharapkan kehidupan dan pengembangan ekonomi masyarakat akan mengalami peningkatan dan kemajuan dalam memperoleh tingkat kesejahteraan.

\section{Pemberdayaan Ekonomi Masyarakat}

Pemberdayaan dalam KBBI memiliki kata dasar "daya” yang artinya kemampuan untuk melakukan sesuatu atau bertindak, pemberdayaan juga diartikan sebagai upaya untuk membangun daya masyarakat dengan mendorong, memotivasi dan membangkitkan 
kesadaran akan potensi serta berupaya untuk mengembangkannya ${ }^{2}$. Sehingga pemberdayaan ekonomi masyarakat diartikan sebagai kegiatan ekonomi yang dilakukan secara swadaya oleh masyarakat itu sendiri dengan cara mengelolah sumberdaya apa saja yang dikuasainya, dalam rangka memenuhi kebutuhan dasarnya dan keluarganya. Pemberdayaan masyarakat hanya bisa terjadi apabila masyarakat itu sendiri ikut pula berpartisipasi ${ }^{3}$.

Pemberdayaan diarahkan guna meningkatkan ekonomi masyarakat secara produktif sehingga mampu menghasilkan nilai tambah yang tinggi dan pendapatan yang lebih layak. Memberdayakan masyarakat harus dilakukan melalui tiga aspek, 1) menciptakan iklim yang memungkinkan potensi masyarakat berkembang dengan memberikan pemahaman bahwa setiap masyarakat mempunyai potensi (berdaya) untuk berkembang, 2) memperkuat potensi yang dimiliki masyarakat (empowering) dengan penyediaan masukan serta membuka akses ke berbagai peluang yang akan membuat masyarakat menjadi semakin berdaya dalam memanfaatkan peluang, 3) melindungi dan mendampingi masyarakat dalam proses pemberdayaan harus dicegah yang lemah jangan sampai menjadi semakin lemah ${ }^{4}$. Sesuai firman Allah yang berbunyi

Artinya :

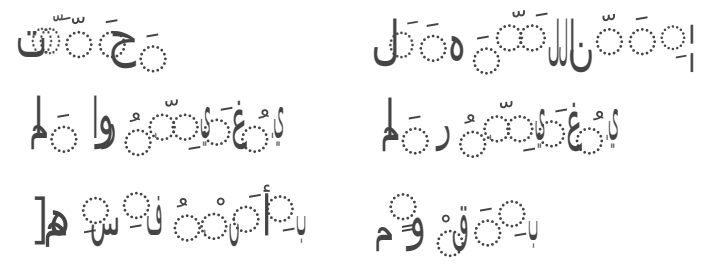

"Sesungguhnya Allah tidak merubah Keadaan sesuatu kaum sehingga

mereka merubah keadaan yang ada pada diri mereka sendiri",5

Untuk meningkatkan ekonomi masyarakat, salah satu upaya yang bisa dilakukan melalui pemberdayaan ekonomi, diantaranya pertama, membangkitkan jiwa seorang wirausaha dalam diri masyarakat. Karena anjuran Islam yang pertama adalah bekerja dan berusaha sebagai upaya dalam mengatasi masalah kemiskinan. Hal ini dilakukan dengan memberikan pelatihan-pelatihan secara berkelompok dengan pendekatan tutor teman sebaya, yang nantinya menjadi bekal yang amat penting dalam memasuki dunia kerja.

\footnotetext{
${ }^{2}$ Ginandjar Kartasasmita, Pembangunan Untuk Rakyat: Memadukan Pertumbuhan dan Pemerataan, (jakarta: PT. Pustaka Cidesindo, 1996), hal. 145.

${ }^{3}$ https://id.wikipedia.org/wiki/Pemberdayaan masyarakat, diakses tanggal 17 agustus 2019

${ }^{4}$ Ginanjar Kartasasmita, Pembangunan Untuk Rakyat, (Jakarta: CIDES, 1996), Hal. 145.
} 
${ }^{5}$ QS Ar Ra"d/13:11) 
Berniaga atau berdagang adalah suatu kegiatan jual beli untuk mendapatkan untung. Berdagang merupakan pekerjaan yang dianjurkan oleh Rasulullah saw, karena berdagang suatu aktifitas yang memiliki manfaat bagi banyak orang, selain memenuhi kebutuhan pribadi, berdagang juga mampu menciptakan lapangan pekerjaan bagi orang lain. Berdagang memiliki manfaat dalam islam diantaranya: 1) menjalin dan menjaga tali silaturahmi, 2) menambah wawasan dan pengetahuan, 3) meningkatkan perekonomian atau menambah penghasilan, 4) melatih kesabaran dan kejujuran, 5) berdagang salah satu ladang pahala, dan 6) merupakan pekerjaan yang halal ${ }^{6}$. Sesuai dengan sabda Rasulullah saw yang menyatakan bahwa "Penjual dan pembeli, keduanya bebas memilih selagi belum berpisah. Maka jika keduanya jujur dan saling menjelaskan dengan benar, maka akan diberkahi pada bisnis keduanya. Namun jika menyembunyikan cacat dan dusta, maka terhapuslah keberkahan jual beli tersebut." (HR. Bukhari dan Muslim). Allah juga menegaskan dalam firmannya yang berbunyi,

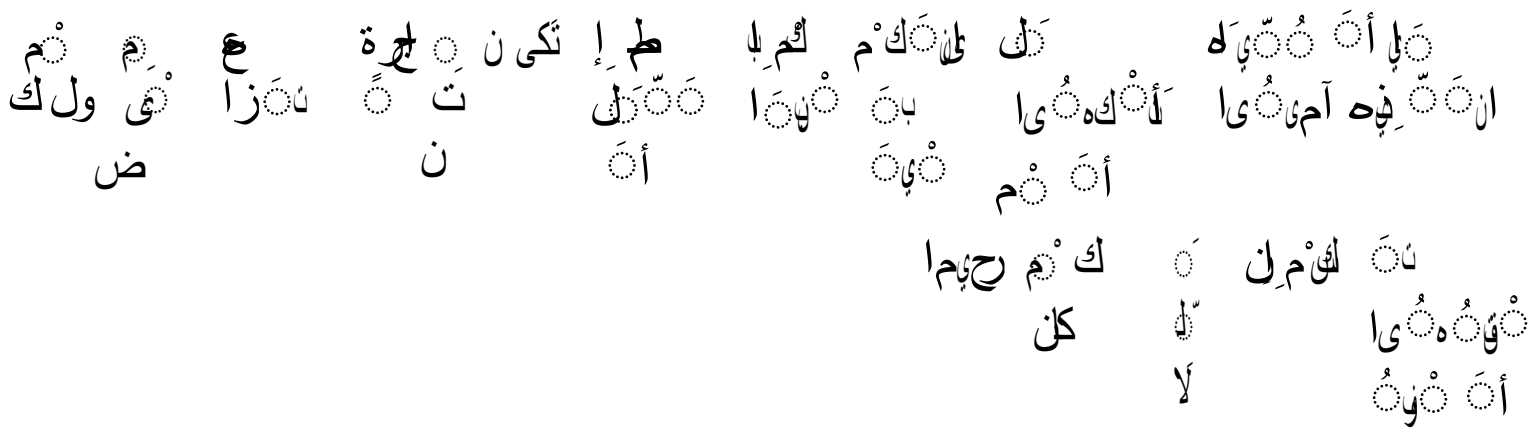

Artinya: "hai orang-orang yang beriman, janganlah kamu saling memakan harta sesamamu dengan jalan yang batil, kecuali dengan jalan perniagaan yang berlaku dengan suka sama suka diantara kamu, sesungguhnya Allah Maha Penyayang (QS. AnNisa' 29).

Dari hadis Rasulullah dan firman Allah tersebut mengisyaratkan kepada manusia bahwa untuk memperoleh keberkahan dalam ekonomi diwajibkan untuk saling menghargai dan menghormati satu dengan yang lainnya agar kegiatan ekonomi berjalan dengan keridhaan Allah.

Warga banjar Angansari yang mayoritas mata pencariannya adalah sebagai petani dan peternak bahkan hanya sebagai buruh tani dan buruh peternak memiliki peluang dalam meningkatkan perekonomiannya melalui berbagai usaha sampingan yang ada 
dilingkungan banjar Angansari. Mereka bisa memanfaatkan kotoran ternak yang diubah menjadi pupuk kandang. Tentu hal ini tidaklah mudah, mereka memerlukan pelatihan dan

\footnotetext{
${ }^{6}$ https://dalamislam.com/info-islami/8-keutamaan-berniaga-dalam-islam, diakses 19 agustus 2019
} 
bimbingan dari pihak pemangku kepentingan seperti pemerintah setempat dan perguruan tinggi yang melaksanakan kegiatan pengabdian pada masyarakat pada banjar Angansari. Hasil pupuk kandang tersebut bisa dipergunakan untuk lahan pertanian penduduk yang membutuhkan dan bisa diperjualbelikan kepada masyarakat lainnya yang membutuhkan. Selain itu warga banjar Angansari juga memiliki peluang lainnya seperti homeindustry. Sehingga dengan adanya usaha sampingan dalam bentuk homeindustri pendapatan warga muslim banjar Angansari mendapatkan tambahan disamping pendapatan utamanya sebagai buruh tani dan buruh ternak. Dan dari hasil buruh tani sebagai pemetik cengkeh mereka bisa mengumpulkan sisa-sisa cengkeh yang telah disortir dan tidak bisa dijual oleh pemiliknya mereka bisa meminta ijin pada pemilik untuk dimanfaatkan sebagai usaha sampingan. Hasil sortiran cengkeh yang tidak bisa dijual bisa dimanfaatkan menjadi tepung/bubuk cengkeh atau sirup cengkeh. Inovasi tersebut juga membutuhkan pelatihan secara khusus dari pihak pertanian dan perguruan tinggi yang membimbing warga Angansari agar mendapatkan hasil yang maksimal. Perlunya kerjasama yang intens antara perguruan tinggi terutama STAI Denpasar dengan pemerintah setempat desa Kutuh Bangli khususnya warga banjar Angansari dalam memberdayakan perekonomian warga melalui berbagai kegiatan pelatihan ketrampilan, penyuluhan UMKM dan penyuluhan koperasi serta kegiatan pengabdian dan penelitian.

\section{Pengadaan home industry.}

Penghasilan warga dari hasil cengkeh rata-rata setiap panen mendapatkan sekitar 3 kwintal, dengan harga cengkeh $1 \mathrm{~kg} \mathrm{Rp.} \mathrm{90.000.} \mathrm{yang} \mathrm{artinya} \mathrm{total} \mathrm{uang} \mathrm{yang} \mathrm{mereka}$ peroleh setiap panen sekitar Rp. 27.000.0007. Rata-rata pengeluaran rumah tangga harian mereka Rp. 80.000 sehingga perbulan Rp. 2.400.000. Jika mengandalkan hasil panen cengkeh saja pemasukan tersebut dirasa masih kurang. Oleh karena itu sangat penting sektor usaha lain sebagai salah satu alternative menambah pendapatan keluarga melalui home industry.

Salah satu usaha di bidang home industry yang berpotensi menjadi peluang usaha adalah di bidang industry makanan. Usaha di bidang industri makanan selalu berada di

\footnotetext{
${ }^{7}$ Hasil wawancara dengan Bpk. Awaluddin
} 
posisi teratas diantara usaha yang lainnya. Salah satunya membuka usaha makanan khas suatu daerah ataupun mengolah suatu bahan yang tidak berguna menjadi sesuatu yang bernilai $^{8}$. Usaha home industry bisa juga dilakukan di Br. Angansari Desa Kutuh mengingat warga muslim disini berdampingan dengan mayoritas non muslim yang bisa dijadikan sasaran konsumen tetap, menurut salah satu warga muslim di desa ini mengatakan bahwa "sebenarnya jika ada orang yang menekuni usaha keripik maka hasilnya akan lumayan, apalagi saat momen hari raya galungan atau kuningan saat orang-orang perantauan pulang kampung dan akan kembali ke tempat perantauan, keripik seperti itu dijadikan oleh - oleh khas" selain itu di desa ini akan dikembangkan potensi pariwisata air terjunnya sehingga memiliki peluang lebih besar dalam memasarkan hasil produksinya. berdasarkan dari hasil pengamatan, usaha home industry yang disarankan masyarakat kurang memiliki minat untuk menjalankan usaha ini dengan alasan hasil yang mereka dapat dari menjual kue dan camilan lebih sedikit dibandingkan hasil sebagai buruh petani cengkeh. Berdasarkan hasil penelitian dan pengangamatan warga di desa ini kurang tekun untuk membuat usaha sampingan, karena mereka lebih memilih untuk bekerja sebagai buruh harian, karena pekerjaan tersebut tidak memakai modal dan bisa langsung mendapatkan uang.

Beberapa faktor yang menjadi penentu tinggi rendahnya minat seseorang untuk berwirausaha adalah dari faktor internal dan eksternal. Faktor internal adalah tidak adanya kemauan dan ketertarikan. Kemauan dalam kbbi bermakna keinginan atau kehendak, sedangkan ketertarikan adalah perasaan senang atau menaruh minat pada sesuatu, salah satu faktor eksternal minat berwirausaha adalah lingkungan dan keluarga. Minat untuk berwirausaha akan terbentuk apabila keluarga memberikan pengaruh positif terhadap minat tersebut, karena sikap dan aktifitas sesama anggota keluarga saling mempengaruhi baik secara langsung maupun tidak langsung ${ }^{9}$. Begitupula dengan faktor lingkungan yang memiliki peran dalam menumbuhkan minat berwirausaha lingkungan yang mayoritas warganya berwirausaha, kemungkinan besar individu yang ada di lingkungan tersebut juga akan berminat terhadap wirausaha. Beberapa daerah yang banyak wirausahanya, sangat berpengaruh dalam menumbuhkan minat berwirausaha

\footnotetext{
${ }^{8}$ https://silamedia.id/bisnis-dan-ukm/peluang-industri-kreatif-2019.html, diakses tanggal 16 September 2019

${ }^{9}$ Alma, Buchari, Kewirausahaan Cetakan ke 1, ( Bandung: Alfabeta, 2007), hal. 7
} 
masyarakat sekitarnya ${ }^{10}$. Faktor lingkungan dan keluarga inilah mungkin yang menjadi penyebab kurangnya minat warga muslim Kutuh untuk mulai berwirausaha. Berdasarkan alasan yang disampaikan oleh beberapa warga Angansari yang kurang berminat terhadap home industry karena mereka harus mengeluarkan dana sebagai modal untuk memulai sebuah usaha rumahan. Sebenarnya apabila warga memiliki motivasi utuk merubah kondisi ekonomi yang pas-pasan mereka bisa melakukan dengan berbagai cara misalnya dengan menabung terlebih dahulu dan merencanakan usaha apa yang hendak dirintis.

STAI Denpasar bekerja sama dengan Baznas mengamati kondisi ini berharap warga Angansari bisa merubah pola pikirnya untuk tidak hanya menjadi buruh tani dan buruh ternak saja melainkan bisa menjadi "majikan" dalam kehidupan ekonominya. Baznas bersedia memberikan bantuan berupa alat pembuat kue/mixer kepada warga Angansari yang memiliki minat untuk berwirausaha. Bantuan alat ini ditujukan kepada ibu rumah tangga selain sebagai buruh tani. Bantuan alat ini diberikan secara cuma-cuma agar warga banjar Angansari memiliki ketrampilan dan bisa memperoleh pendapatan tambahan dari hasil membuat kue yang dijual atau dititipkan ke warung-warung di desa Kutuh. Hasil ketrampilan diharapkan bisa dikembangkan lebih banyak lagi mengingat bahwa di desa Kutuh memiliki potensi ekonomi yang berasal dari pariwisata. Pariwisata yang akan direncanakan adalah kawasan pariwisata air terjun yang berada di tengah hutan, rencana ini sudah mendapat persetujuan dari Menteri Kehutanan dan saat ini dalam proses pembuatan jalan bersemen sebagai akses menuju air terjun. Potensi ekonomi bidang pariwisata ini tentunya berimbas pada perkembangan home industry baik di bidang makanan atau aksesoris serta berpeluang dalam perkembangan koperasi syariah bagi warga muslim banjar Angansari.

\section{Pengadaan Koperasi Syariah}

Warga muslim banjar Angansari desa Kutuh belum memiliki sarana pembiayaan untuk kegiatan ekonomi seperti koperasi atau lembaga simpan pinjam pada umumnya. Sehingga warga banjar Angansari merasa kesulitan apabila membutuhkan modal untuk memulai suatu usaha. Pada saat penulis melakukan penelitian dan melakukan wawancara dengan warga banjar Angansari sebenarnya mereka sangat membutuhkan adanya lembaga

${ }^{10}$ ibid 
atau badan pembiayaan semacam koperasi, namun mereka kesulitan dengan adanya modal awal yang dimiliki untuk operasional koperasi tersebut mengingat bahwa pendapatan mereka selama ini habis untuk kebutuhan sehari-hari. Warga banjar Angansari juga merasakan kesulitan dalam mengumpulkan warga untuk mengadakan komunikasi karena kesibukan masing-masing sebagai buruh tani dan ternak. Oleh karena itu peneliti menyarankan untuk membentuk koperasi berdasarkan syariah, mengingat bahwa warga banjar Angansari adalah warga muslim. Perlunya koperasi berdasarkan syariah agar warga banjar Angansari tidak terjerat oleh praktek riba. Pemerintah juga memberikan peluang kepada masyarakat melalui lembaga yang ada untuk membentuk koperasi, terutama yang berdasarkan syariah karena saat ini pemerintah melalui KNEKS sedang melakukan pengembangan ekonomi dan keuangan syariah secara global. Berdasarkan alasan tersebut peneliti kemudian melakukan sosialisasi tentang koperasi syariah. Agar warga banjar Angansari memiliki pengetahuan tentang koperasi syariah secara mendalam. Peneliti kemudian menjelaskan tentang apa itu koperasi syariah, peran, fungsi, tujuan, dan syarat usaha koperasi syariah.

Menurut Pasal 1 Kementerian Koperasi UKM RI tahun 2009, koperasi syariah adalah bentuk koperasi yang segala kegiatan usahanya bergerak di bidang pembiayaan, simpanan pokok, sesuai dengan pola bagi hasil "Syariah" dan investasi. Tujuan koperasi ini adalah untuk membantu meningkatkan masyarakat luas, khususnya para anggota koperasi dan juga kesejahteraan masyarakat secara umum, serta membangun perekonomian Indonesia sesuai prinsip-prinsip Islam. Pemerintah dan swasta, meliputi individu maupun masyarakat, wajib mentransformasikan nilai-nilai syari’ah dalam nilai-nilai koperasi, dengan mengadopsi 7 nilai syariah dalam bisnis yaitu : a). Shiddiq yang mencerminkan kejujuran, akurasi dan akuntabilitas. b). Istiqamah yang mencerminkan konsistensi, komitmen dan loyalita, c). Tabligh yang mencerminkan transparansi, kontrol, edukatif, dan komunikatif, d). Amanah yang mencerminkan kepercayaan, integritas, reputasi, dan kredibelitas,e). Fathanah yang mencerminkan etos profesional, kompeten, kreatif, inovatif.f). Ri'ayah yang mencerminkan semangat solidaritas, empati, kepedulian, awareness.g). Mas'uliyah yang mencerminkan responsibilitas. Koperasi yang berlandaskan ajaran Islam ini mempunyai tujuan untuk meningkatkan kesejahteraan anggota pada khususnya dan masyarakat pada umumnya serta turut membangun tatanan perekonomian yang 
berkeadilan sesuai dengan prinsip-prinsip Islam. Selain nilai-nilai syariah diatas koperasi syariah memiliki fungsi dan peran sebagai berikut :

a. Membangun dan mengembangkan potensi dan kemampuan anggota pada khususnya, dan masyarakat pada umumnya, guna meningkatkan kesejahteraan sosial ekonominya.

b. Memperkuat kualitas sumber daya insani anggota, agar menjadi lebih amanah, professional (fathonah), konsisten, dan konsekuen (istiqomah) di dalam menerapkan prinsip-prinsip ekonomi islam dan prinsip-prinsip syariah islam.

c. Berusaha untuk mewujudkan dan mengembangkan perekonomian nasional yang merupakan usaha bersama berdasarkan azas kekeluargaan dan demokrasi ekonomi.

d. Sebagai mediator antara menyandang dana dengan penggunan dana, sehingga tercapai optimalisasi pemanfaatan harta.

e. Menguatkan anggota, sehingga mampu bekerjasama melakukan kontrol terhadap koperasi secara efektif.

f. Mengembangkan dan memperluas kesempatan kerja. Menumbuhkan-kembangkan usaha-usaha produktif anggota.

Prinsip dari koperasi syariah adalah sebagai berikut :

a. Kekayaan adala amanah dari Allah SWT dan tidak bisa dimiliki sepenuhnya oleh siapapun secara mutlak.

b. Setiap manusia berhak dan diberi kebebasan untuk bermu'amalah selama hal tersebut sesuai ketentuan syariah.

c. Setiap manusia berhak dan diberi kebebasan untuk bermu'amalah selama hal tersebut sesuai ketentuan syariah.

d. Umat manusia ialah khalifah Allah dan pemakmur di muka bumi ini.

e. Menjunjung tinggi keadilan, secara menolak semua yang berhubungan dengan ribawi dan pemusatan sumber ekonomi pada sekelompok orang. 
Dalam proses operasional, koperasi harus memenuhi persyaratan tertentu, seperti:

a. Semua kegiatan dalam koperasi merupakan kegiatan bisnis yang sah, baik, bermanfaat, dan menguntungkan dengan sistem bagi hasil.

b. Koperasi wajib menjalankan fungsi dan perannya sebagai lembaga keuangan sesuai yang tercantum dalam sertifikasi bisnis koperasi.

c. Setiap bisnis yang dijalankan oleh koperasi ini harus mengacu pada fatwa dan ketentuan Dewan Syariah Nasional Dewan Ulama Indonesia.

d. Setiap bisnis yang dijalankan oleh koperasi ini tidak boleh bertentangan dengan hukum dan peraturan yang berlaku di Republik Indonesia.

Berdasarkan paparan diatas tentang peran, fungsi dan syarat usaha koperasi syariah diatas peneliti memberikan saran dan masukan kepada warga banjar Angansari untuk membuka peluang usaha melalui koperasi syariah sebagai sarana untuk pendanaan usaha yang mereka lakukan. Agar pemberdayaan ekonomi warga banjar Angansari bisa terwujud dan terlaksana baik melalui pemberdayaan usaha tani dan ternak, homeindustri serta pemberdayaan ekonomi melalui koperasi syariah.

\section{KESIMPULAN}

Berdasarkan pembahasan diatas maka peneliti dapat menyimpulkan potensi ekonomi yang dimiliki oleh warga banjar Angansari adalah potensi ekonomi yang berasal dari hasil pemberdayaan ekonomi, yaitu dari hasil usaha tani dan ternak, pengadaan homeindustri sebagai usaha sampingan dan penunjang menambah pendapatan keluarga serta pengadaan koperasi syariah sebagai sarana pendanaan usaha bagi warga banjar Angansari yang membutuhkan modal dalam rangka membuka usaha. Dengan adanya pemberdayaan potensi ekonomi diharapkan warga banjar Angansari desa Kutuh Kintamani Bangli bersiap menghadapi dibukanya sektor pariwisata desa Kutuh tidak lama lagi.

\section{DAFTAR PUSTAKA}

Alma, Buchari, Kewirausahaan Cetakan ke 1, Bandung: Alfabeta, Th. 2007. 
Kartasasmita ,Ginandjar, Pembangunan Untuk Rakyat: Memadukan Pertumbuhan dan Pemerataan, Jakarta: PT. Pustaka Cidesindo, 1996,

Wawancara dengan Bpk. Awaluddin, warga banjar Angansari Desa Kutuh Kintamani Bangli.

https://ajaib.co.id/apa-itu-koperasi-syariah-pelajari-di-sini-yuk, diakses Januari 2021

http://bali.bps.go.id/statictictable/2018/02/15/33/penduduk-provinsi-bali-menurut-agamayang-dianut-hasil-sensus-penduduk-2010.html

https://dalamislam.com/info-islami/8-keutamaan-berniaga-dalam-islam, diakses 19 Agustus 2020

https://silamedia.id/bisnis-dan-ukm/peluang-industri-kreatif-2019.html, diakses tanggal 16 September 2020

https://id.wikipedia.org/wiki/Pemberdayaan_masyarakat, diakses tanggal 22 Agustus 2020 